\title{
A CIRCADIAN SUSCEPTIBILITY-RESISTANCE CYCLE TO FLUOTHANE IN MALE $B_{1}$ MICE*
}

\section{James H Matthews, m d, Egon Makte, m d, and Franz HaLberg, m d $†$}

BECAUSE THE POTENCY and margin of safety of Fluothane are topics of current interest, we are reinvestigating the toxicty of Fluothane using the mouse and the method of indirect periodicity analysis ${ }^{1}$ This paper presents pertinent expenmental results

Several earlier studies of Fluothane toxicity in the mouse constitute avalable background information In his first study, Raventós ${ }^{2}$ found the $L D_{50}$ of Fluothane vapour in oxygen to be 28 per cent ( \pm 034 per cent) during 30 minutes of exposure In a later article, Raventós and $D^{3} e^{3}$ reported the value to be 316 per cent Krantz, Park, Truitt, and Ling ${ }^{4}$ found a value of 31 per cent using 5 minutes of exposure and different vaporization techniques Study of Mørch and Jobgen's data ${ }^{5}$ from tests with 10 minutes of exposure suggests a higher $\mathrm{LD}_{50}$ of between 35 and 40 per cent On the other hand, Jones, Margolis, and Steven ${ }^{6}$ observed no deaths after the intraoesophageal instillation of 100 per cent Fluothane Because these lines of work were reported without reference to temporal aspects of tests conditions (discussed elsewhere ${ }^{7}$ ), it seemed desirable for us to employ techniques of indirect periodicity analysis for the bio-assay of Fluothane toxicity

The reliability of bıo-assay techniques depends upon many factors ${ }^{8}$ It increases with the extent to which one pays attention to vanables such as the genetic background, sex, and past history of an animal population, as well as to test conditions Pertinent factors stem from the physical environment to which animals are exposed before and during testing, including still other sources of variation ranging from diet to infection Some of these parameters of bio-assay have temporal facets The age of test animals is the most obvious time factor Less well known is the role in bio-assay of another temporal parameter, the stage of physiologic rhythms with periods of about one day These so-called circadian (circa, dies $)^{79}$ rhythms can critically determine the outcome of a mammal's exposure to a variety of agents ${ }^{10-16}$

Studies of drug effects done at different times of the day that do not further specify conditions of observation may seem pertınent, although they are not identical in approach ${ }^{17-19}$ Actually, an indication of an hour of the clock for increased or decreased susceptibility is meaningful only under standardized

'Condensed from a paper presented at the Western Divisions' Meetung, Canadian Anaesthetists' Society, held in Edmonton, Alberta, in March 1962 Supported by grants from the US Public Health Service [No H-1983 (C-7) and No 5-K6-GM-13981-03, NB-04531-02], The Amencan Cancer Society (No E-155E), and the Graduate School of the University of Minnesota

fFrom the Departments of Anesthesiology and Pathology, Unxversity of Minnesota College of Medical Sciences, Minneapolis, Minnesota 
conditions ${ }^{1}$ Those unfamiliar with physiologic periodicity analysis should note that by manipulating the lighting regimen to which certain experimental animals are exposed, and by several added precautions, ${ }^{7}$ one may shift the peak and trough of a susceptibility rhythm to any clock hour of one's chorce ${ }^{20}$ Without reference to the lighting regmen and other factors, ${ }^{7}$ studies of drug effects solely at different clock hours, therefore, are of restricted, if any, value They may, at times, confuse the issues on hand, and as long as conditions of observations are not standardized, the results may be quite varnable

When temporal and other factors in bio-assay are taken into account to a certain extent, as in the present study, the results are surpusing the mortality of mice after exposure to 35 per cent Fluothane for 7 to 10 minutes demonstrates a circadian susceptibility-i esistance cycle The mortality from a given dose of Fluothane may be as low as 5 per cent or as high as 76 per cent, depending upon the organism's circadian system phase

\section{Materials and Methods}

Three experiments were done on male inbred mice of the $\mathrm{C}_{57}$ Black, subline 1 stock (bivefly, $\mathbb{B}_{1}$ ) This strain has been maintaned by biother-to-sister mating for more than 10 years, in the Department of Pathology at the University of Minnestota Medical School The experimental mice were kept multıply-housed, with Purina Fox Chow and tap water freely avallable from weaning and throughout the study

One week prior to a given experiment, anımals were transferred to disposable cages measuring $40 \times 32 \times 9 \mathrm{~cm}-6$ or 7 mice to a cage The cages were placed in a room shielded from natural light and sound, mamtaned at $24 \pm 1^{\circ} \mathrm{C} \mathrm{A}$ clock-controlled switch turned the lights in the room on at 0600 and off at 1800 each day

On the day of study, separate groups of anmals were tested at four-hourly intervals, staitung at 0800 of one day and ending at either 0400 or at 0800 of the next day A group was composed of 14 to 21 mice The mice constituting different groups in a given experiment were comparable not only in terms of genehc background and sex, but also in terms of age

The anaesthetic concentration was prepared using a Herdbrink 660X Kinet oMeter to provide an oxygen flow rate of 4 litres/minute into a Mark II Fluotec vaporizer, $\uparrow$ set at the 35 per cent marking A model 10 Fluothane Monitor + of the infrared type served to check the accuracy of the vaporizer

The anaesthetic chamber consisted of an 8 litre desiccator with a wire mesh platform restung across the glass ledge near the bottom Several minutes before the start of a test 35 per cent Fluothane in oxygen was introduced at 4 litres/ minute into the bottom of the chamber, by rubber tubing ending below the platform

Mice from a given cage were then thansferred into the chamber Anaesthetic yapour contmued to flow into the bottom of the chamber dunng transfer and

Ohro Chemical and Surgical Equipment Co, Madison, Wisconsin

TFraser Sweatman, Inc, Buffalo, New York

Analyhcal Systems Company, Pasadena, Califorma 
throughout the next 10 minutes Excess vapour escaped through a hole in the hd After 10 minutes of exposure the wire platform holding the mice was lifted out and placed on a table in room arr

The same procedure for anaesthesia was repeated for subgroups of mice from consecutive cages, at each time-point chosen for study Total test time required for mice from a group of cages (at least two, but usually three cages) did not exceed 45 minutes The anmals were under contnuous observation in the chamber and thereafter, until death or recovery from anaesthesia Recovery was judged by return of the righting reflex The time of death or recovery was followed with a stopwatch, starled when the mice were transferred into the desiccator Results were recorded for consecutive one minute intervals

\section{Results}

Figure 1 shows the results of the three experiments Test-time, given in clock hours on the abscissa, is roughly the mil-point of the total period elapsed from start to end of testing a group of mice The lighting regimen on which mice were kept for a week prior to study and up to a minute pror to testing also is indicated above the abscissa, black areas denoting darkness During anaesthesia and thereafter the mice were kept in light at all times The percentage of deaths from anaesthesia at each test-time is shown on the ordinate

In the experment recorded on the left 137 mice were used, 147 in that shown in the middle, and 125 animals comprise the right-hand graph The mean age in days (and standard error) of these three sets of mice was, in this order, 83 $( \pm 1), 116( \pm 1)$, and $283( \pm 2)$ days, respectively Mice summarized in the right-hand plot were thus much older than those described on the left or in the middle

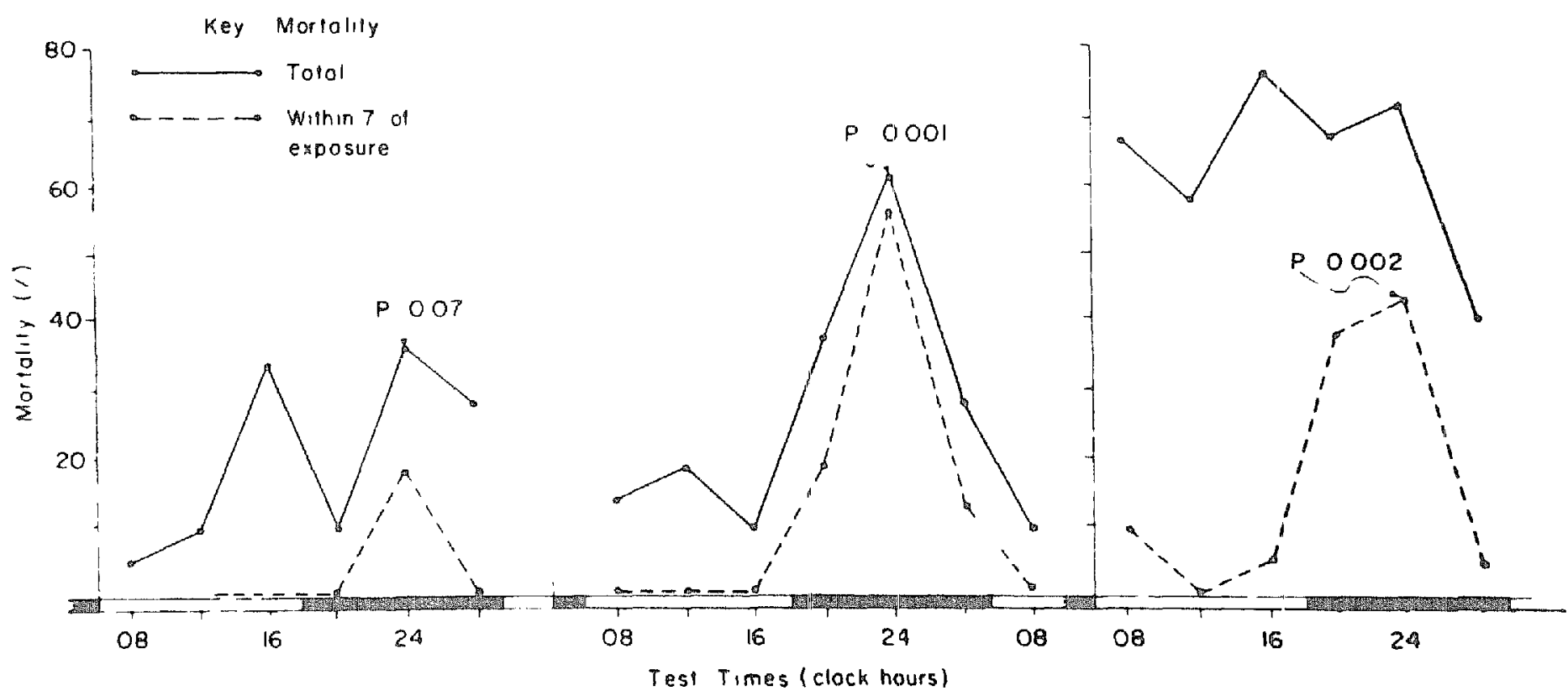

Figure 1 Dependence of Fluothane toxicity upon circadian system-phase Three expenments on male $B_{1}$ mice of three age groups Experment on youngest mice on the left, those on older animals on the nght (see text) In each expenment the 10-minute exposure of separate groups of comparable animals to 35 per cent Fluothane was associated with differences in mortality as a function of exposure time $\mathbb{P}$ values denved according to procedure for analysing the statustical significance of crests in physiolognc tume senes ${ }^{21}$ 
The curves with solid lines show that total mortality, expressed as per cent of total tested, varied from 5 to 76 per cent, according lo test time and age The greatest mortality was among older mice-the plot on the right Since the three experiments were done on dufferent days, the age effect awaits further intraexperimental validation

Plots of mortality in a given expenment, in their turn, suggest differences related to test time These were analysed by a statistical procedure ${ }^{21}$ described and proposed earher for indirect penodicity analysis ${ }^{1}$ From this test of the statustical significance of the crest in mortality occurring at 2400 in the experiment recorded on the left side of $\mathbb{F}$ igure 1 , a $\mathbb{P}$ value of 007 was obtanned For the data in the middle of the figure the corresponding $P$ value was less than 0001

An evaluation of the crest in total mortality was not done on the data of the third experiment At the time of the first exposure (0800) it was observed that the 35 per cent dose of Fluothane was too great for mice of this age Since a high percentage of mice of this first group died within 10 minutes, it was decided at the outset, $1 \mathrm{e}$, at the first test-tume, that the expernment be continued with

SUSCEPTIBILITY RHYTHM TO FLUOTHANE

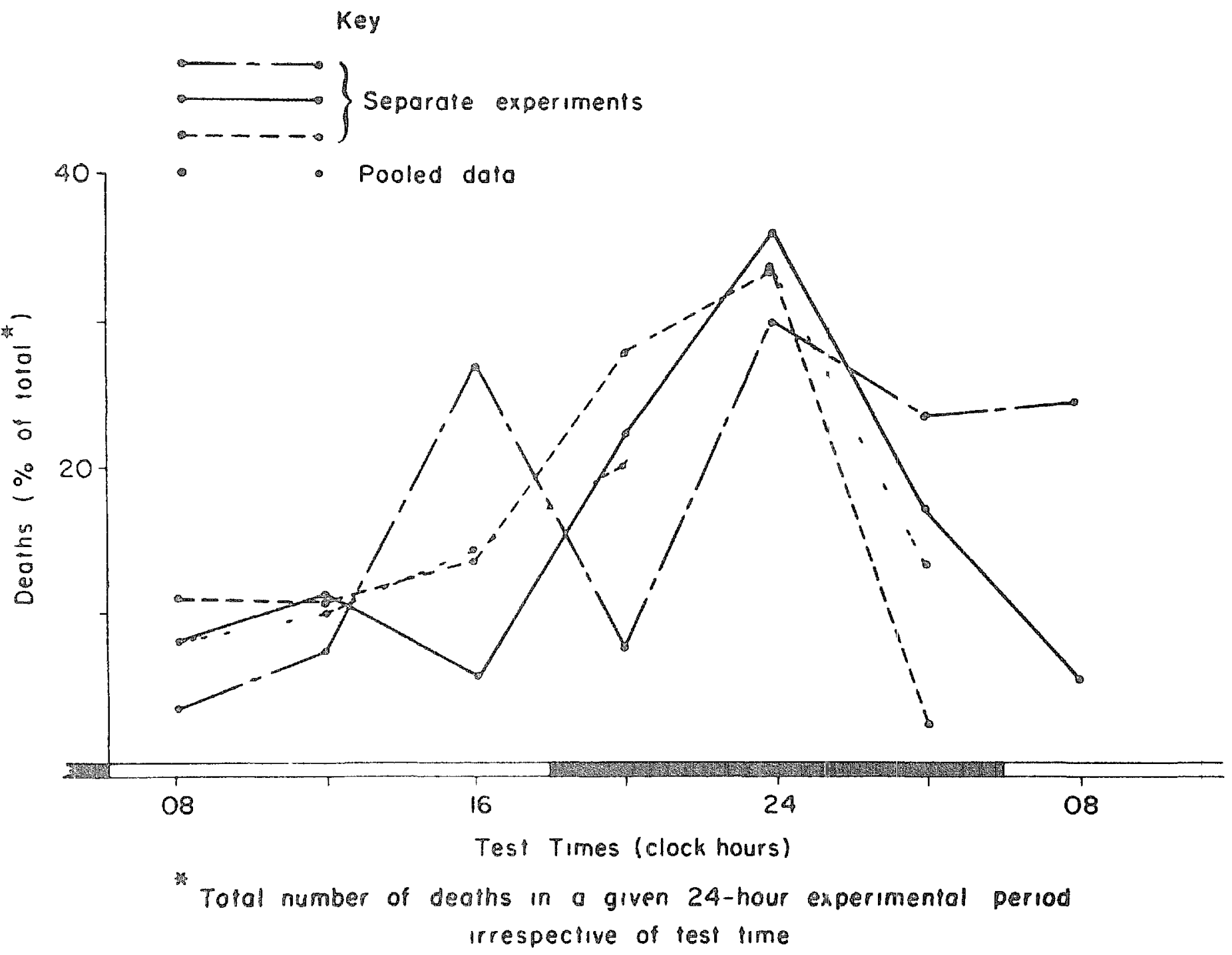

Figure 2 Data from Figure 1 re-expressed as percentage of total mortality in a givien experument on mice of a given age Transformation reduces effect of differences in level of susceptubility or resistance to Fluothane as a function of age The temporal change in susceptrbility oi resistance as a functon of circadian system-phase, rather than age, can now be seen from the pool of data from all three expenments (see text) 
10-minute exposures, as onginally planned, but that results be evaluated according to the mortality occurring within the first 7 minutes, rather than during the enture 10 minutes of exposure Analysed on this basis, $1 \mathrm{e}$, in terms of the data summarzed by the dashed line, the crest at 2400 in the right-hand graph is statistically sigmificant, with a $P$ of 0002

For companson, the deaths occurring wrthin 7 munutes of exposure in the other two experiments also are shown by dashed lines Viewing the seven-minute data as well, it can be seen that mortality at 2400 is much higher than at other tumes Note, for instance, that in the experument plotted on the left, no deaths had occurred prior to the seventh minute at any time except at 2400

Figure 2 shows mortality expressed in percentage of total mortality in a given experiment For the first two experments all deaths were included in this computation Deaths occurring after the seventh minute of exposure in the last experment were excluded from calculation, for the reasons stated above The three curves are roughly congruent, then mean is shown as a dotted line

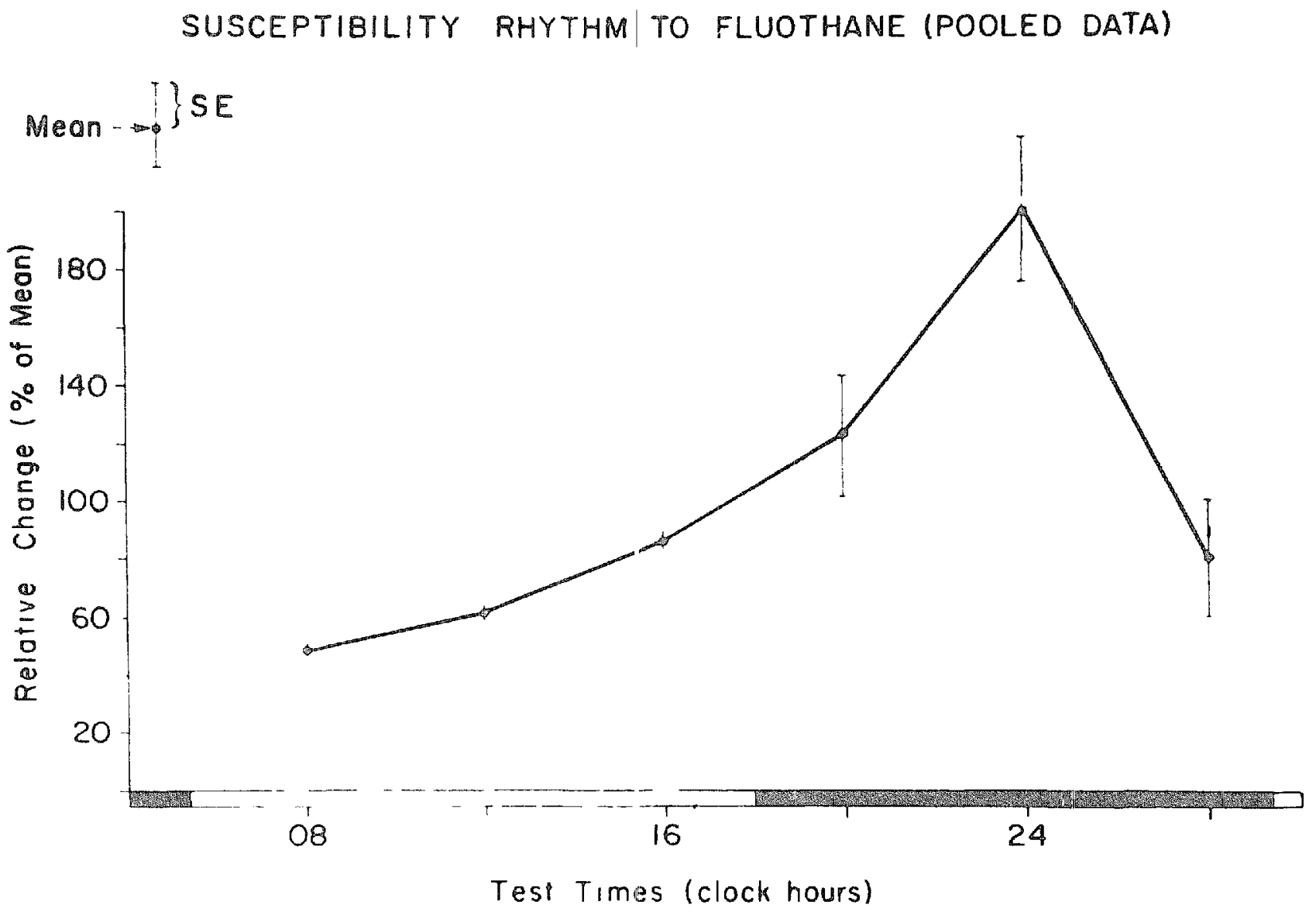

FIcure 3 Conversion of the pooled data in Figure 2 anto "relative changes" estumates of virabilnty also provided for results from each test-tume

The crest in mortality at 2400 is apparent from this summary presentation as well as from the solid line in Figure 3 , which shows the so-called "relative change"22 in susceptibillty to Fluothane To obtain the curve in Figure 3, mortality at a given test-tume was expressed as a percentage of the average mortality in a given expenment, with the latter mean equated to 100 per cent Thereafter, these relative values for each test-tume were averaged to obtaun the mean relative change, plotted in Figure 3 


\section{Discussion}

These experiments involving a 7 or 10 mmute exposure to 35 per cent Fluothane in oxygen demonstrate, first, a circadian susceptibility-resistance cycle to this agent Secondly, the data also suggest, but do not prove, a difference in susceptibility among different age groups The location of the crest in suscept1bullty at 2400 and the influence of differences in agge were antucipated on the basis of previous studies using another agent affectung the CNS-Librium $\left(\mathbb{F}_{1 \mathrm{~g}} 4\right)^{15,16}$

Along the same line, it is interesting that the susceptibility of mice to ethanol ${ }^{14}$ and audiogenic convulsions, ${ }^{101120}$ tested under comparable conditions, is highest at about 2000 (Figs 5 and 6) ${ }^{23}$ The location of the arests of these susceptibility rhythms shows relatively small, if any, differences in phase Pertinent also are circadian susceptibility rhythms with a similar timing described by Davis for pentobarbital ${ }^{24}$ and by Davis and Webb for hexafluorodiethyl ether, ${ }^{25}$ as well as a most recent study on Nembutal by Emlen and Kem ${ }^{26}$ The response of rodents to all of these agents affecting the CNS thus appears to depend upon a similar curcadian system phase, awantung further definition. Susceptibility rhythms to

Circodian Suscepibility Rhyihm to Librium

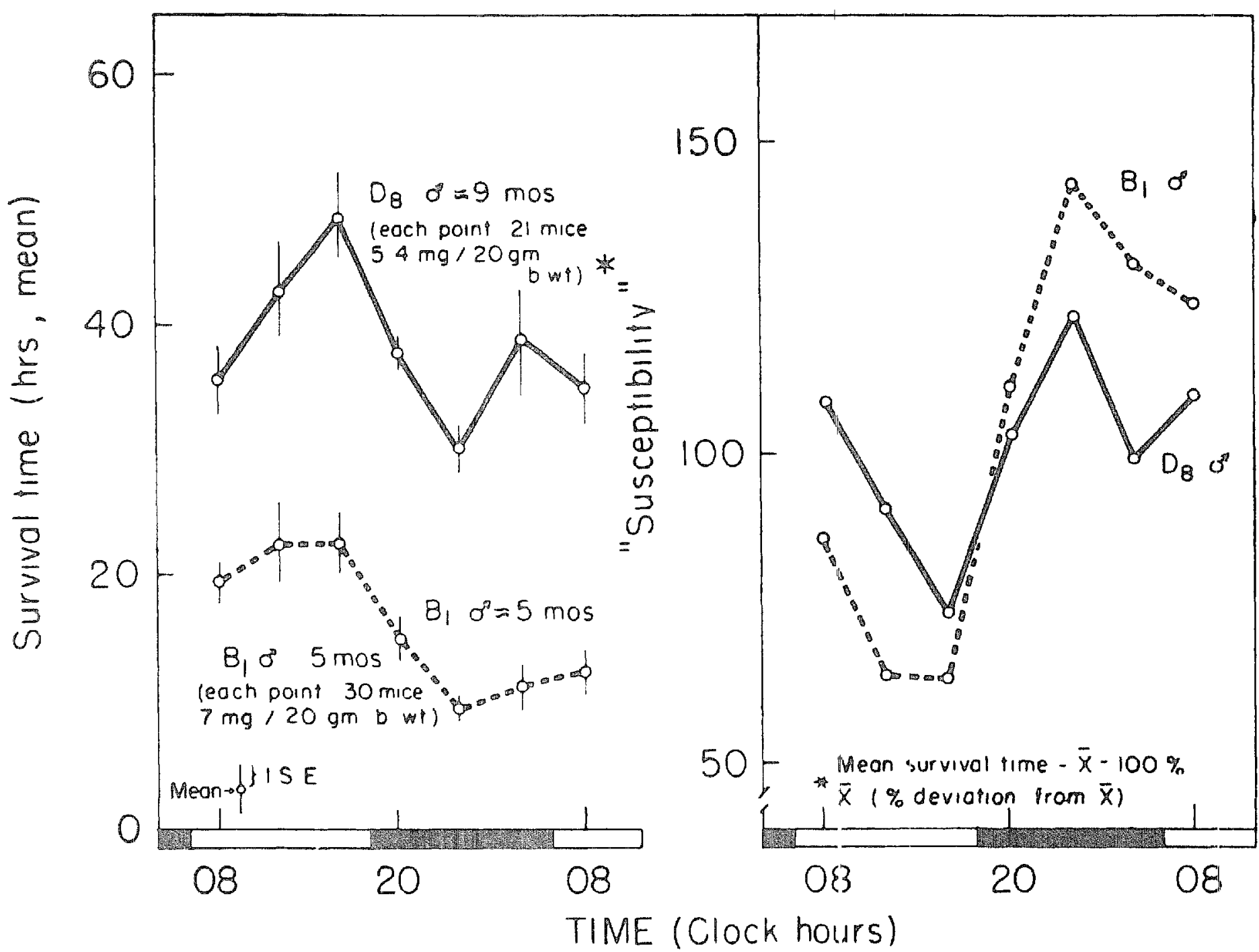

Figure 4 Circadian susceptibility-resistance cycle to Libnum By contrast to Figures $\mathbb{I}-3$, data in the left half of thas figure are expressed in terms of curvival ame rather than as per cent deaths Transformed data on the nght of figure ${ }^{1010}$ 


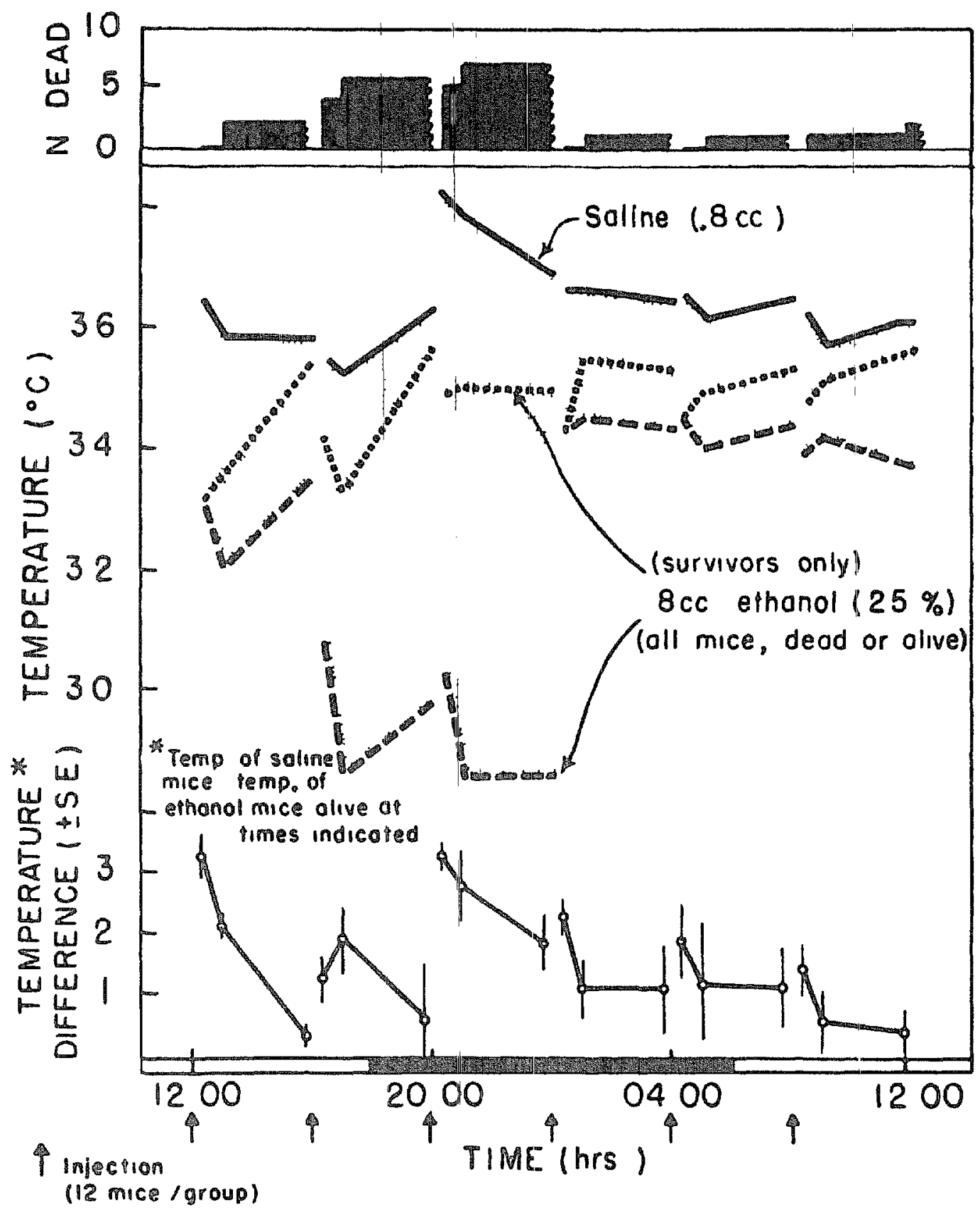

Figure 5 Circadian susceptibility-resistance cycle to ethanol Black columns on top of figure denote mortality of comparable male $\mathbb{C}$ mice, 4 months \pm 2 weeks of age, injected $1 \mathrm{p}$ with $08 \mathrm{cc}$ of a 25 per cent solution of ethanol in saline Ethanol-induced hypotherma as well as mortality from ethanol depends upon circadian systemphase at injection time Detalls of this experiment and of confirmatory ones are in References 1 and 14

other agents, however, peak at quite different tumes, as shown in Figure 7, summarizing the so-called "hours of changing resistance" 1

These predictable physiologic changes in susceptibility of mammals to drugs would be important as models for clinical studies if toxic-therapeutic ratios also can be found to vary depending upon an organism's circadian system phase For example, anaesthetıcs with undesirable cardiovascular side-effects, such as Fluothane, might have a relatively small margin of safety if at a given time the organism exhibits an increased susceptibility to cardiovascular disturbances and concomitantly a decreased susceptibility to cortical depression In other words, the same amount of drug might produce the desired effect and little undesirable side reactions at one tume ( $1 \mathrm{e}$, circadian system phase) and at another tume considerable side reactions with little desirable effect 


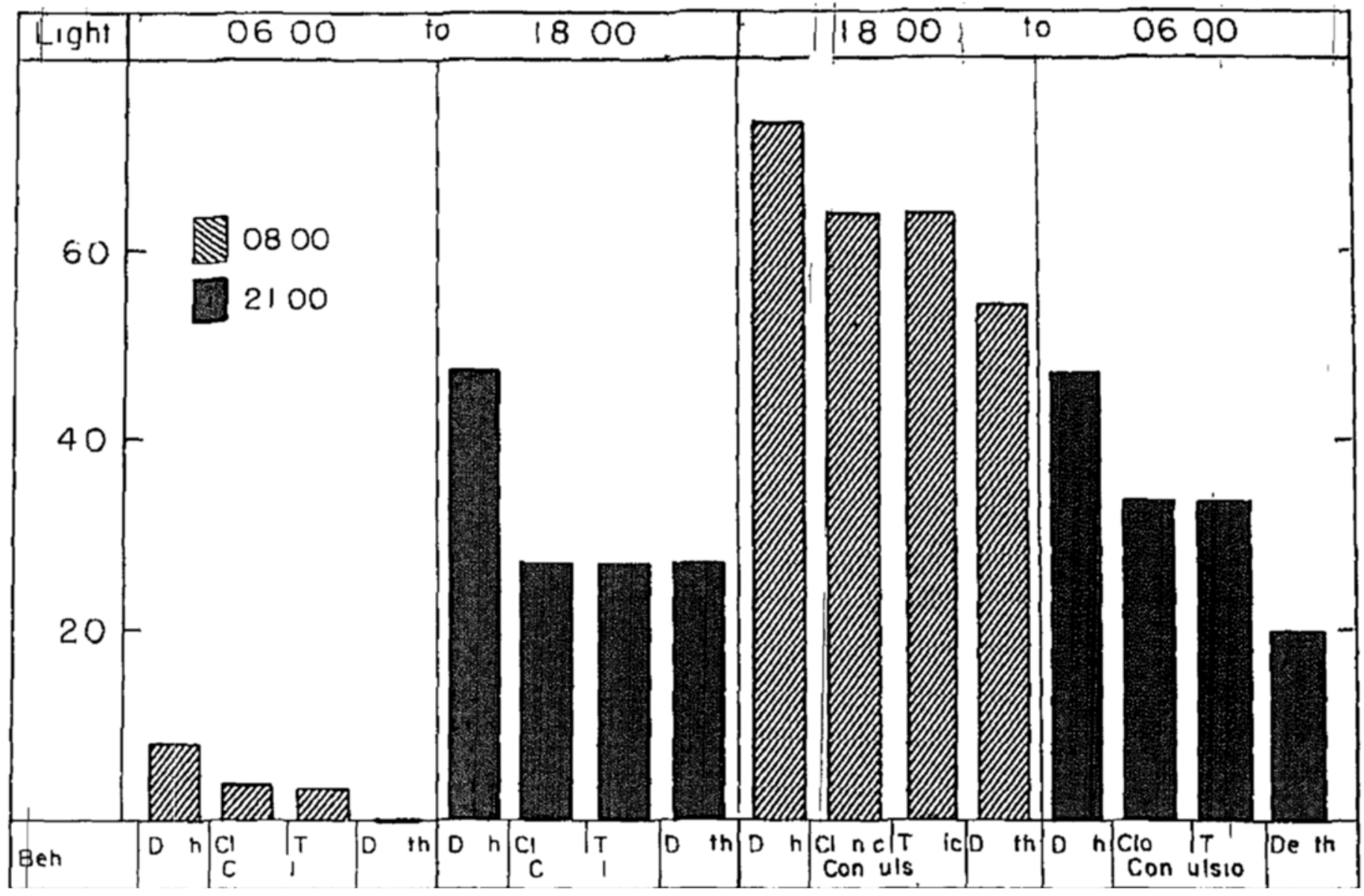

Ficure 6 Abnormal audiogenic resonses in $D$ mice on two schedules of light and darkness alternating at 12-hour intervals Incidence of several types of nouse-induced abnormality duffers at 0800 as compared with 2100 in mice exposed to light from 1800 to 0600 as compared with that in mice exposed to light from 0600 to 1800 Note feasibility of phase-shifting of a cer cadian susceptibulity resistance cycle Total tested 120 mice about five weeks of age of both sexes ${ }^{20}$

We must qualify these intual experimental data on Fluothane in several ways Furst, in speaking of certain phases of susceptibility rhythms such as a crest we mean to refer to curcadian system phase rather than to clock hour We do so since a given phase of circadian rhythm can be shifted to any clock hour of ones chorce by manipulatung the envronment $027 \mathrm{We}$ also must refer to a number of technical problems One of these revolves around the accuracy of the Fluotec vaponzer This question was resolved for the time being only through verification of the $v$ ipour concentration provided by infrared analysis and through consistent use of the same flow rate and vaporizer settngs Subsequent experments have necessitated a more accurate system and one which permits the study of other anaesthetic vapours and gases

A second technical problem resulted from a small water leak in the penodicity room but not into the cages containing the mice represented by the left hand graph of Figure 1 The effect of the noise from dripping water remains unevalu zted

In subsequent studies we are extending the design not only to replicate the curcadian susceptibility rhythms but also to test within various expenments the influencis of age sex strain vanations in dosage of Fluothane premedication and other common anaesthetic factors More accurate observation of induction 


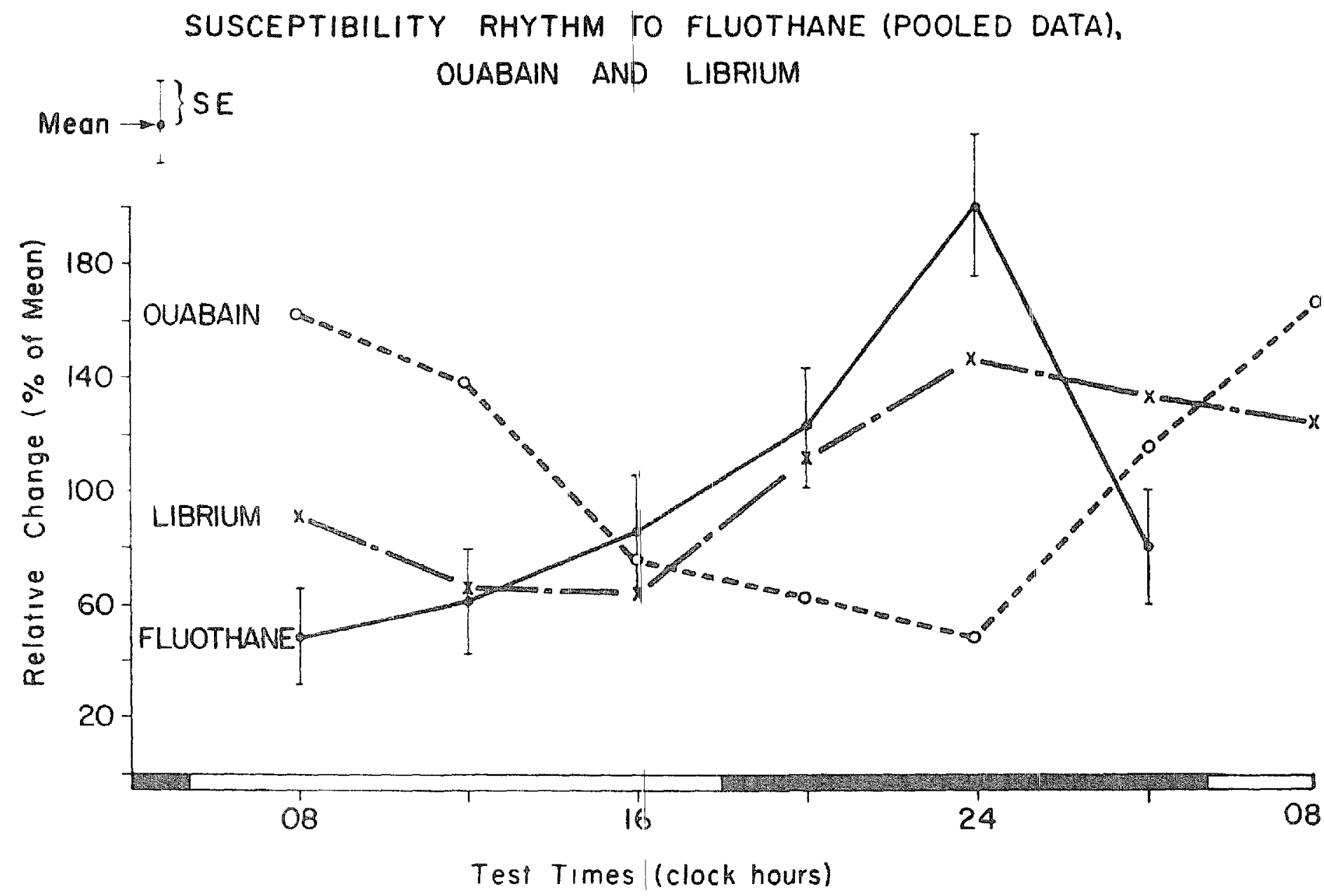

Figure 7 The concept of hours of changung resistance can be further documented by data on Fluothane (- - The data of this paper are aligned with some obtained on other susceptibility-resistance cycles earlier This figure should convey the degree of generality of changes in response to toxic doses of several drugs as a function of circadian system-phase The same figure may be used further to suggest that crests and troughs in susceptiblity to different agents do not all occur at the same time circadian synchronization occurs with differences in phase, some of which are positive or negative, as well as zero (Cold Spring Harbor Symposia on Quantitative Biology, vol 25, Long Island Biological Association, New York, 1960, p 524)

tumes, anaesthetic levels, and respuratory and cardiovascular responses may help to clarify mechanısms of death

The importance of these initial studies to anaesthesiologists may be the demonstration that circadian rhythms characterize the susceptibility of a mammal to Fluothane, and the suggesion that circadicin penodicity analysis of therapeutictoxic ratios may eventually contribute to a better understanding of the lethality and margin of safety of anaesthetics

\section{SUMMARY}

The mortality of mature, male $\mathbb{B}_{1}$ mice upon exposure to 35 per cent Fluothane in oxygen for 10 minutes may be as low as 5 per cent or as high as 76 per cent, depending upon the organism's circadian system phase, Predictably per iodic changes in susceptibility can be found in test anımals of several age groups, apart from differences in susceptibility as a function of age Further consideration of the organism's time structure, as revealed by its rhythms, may lead to safer anaesthetic practices 


\section{RÉSUMÉ}

Nous faisons une étude de la toxıcité de l'halothane, en nous servant de sourns et de la méthode d'analyse de périodicité indirecte Ce travall rapporte des résultats expérimentaux sur une cycle curcadien (crrca, dies, un rhythme dont la pénode esi d'environ 24 heures) dans la resistance d'un organisme vis-à-vis de l'halothane En tenant compte du facteur temps et de facteurs de technique biologique expérmentale, la mortalıté de souns $\mathbb{B}_{1}$ mâles-ayant respiré des vapeurs d'halothane à 35 pour cent dans l'oxygène durant 7 à 10 minutes-aurast varié de 5 à 76 pour cent selon la phase du système circadien, $1 \mathrm{e}$, la distubution des temps internes de l'organisme ( fig 3) Ces résultats étarent à prévoir d'après les études anténeures sur le librium, sur l'éthanol, sur les convulsıons audıogéninques, sur le pentobarbital et sur l'éther hexaflurodiéthylique La discussion de ces travaux soulève la question de l'amélioration possible de la pratıque de l'anesthésie, si ces données s'appliquent au rapport toxicité/thérapeutique des agents anesthésıques

\section{REFERENCES}

1 HALBERG, F Circadian Rhythms, a Basis of Human $\mathbb{F}$ ingmeering for Aero-Space In Psychophysiological Aspects of Space Flight, eduted by B Flaherty p 166 New York Columbia University Press ( 1961 )

2 Raventós, J The Action of Fluothane, a New Volatile Anaesthetic Brit J Pharmacol 11394 (1956)

3 Raventós, I \& DeE, J The Action of the Halothane-Diethyl Ether Azeotropic Mixture on Experimental Animals Brit J Anaesth 3146 (1959)

4 Krantz, J C, Park, C S, Truitr, E B, \& Ling, A S C Anesthesia LVII A Further Study of the Anesthetic Properties of 1,1,1 Trifluoro-2,2 bromochlorethane (Fluothane) Anesthesiology 1938 (1958)

5 MørсH, E T \& Jobgen, E A Fluothane Compared to Chloroform and Ether in Mice Acta Scand Anaesth 3173 (1959)

8 Jones, W M, Margolis, G, \& SteveN, C R Hepatolosity of Inhalation Anaesthetic Drugs Anesthesiology 19715 (1958)

7 HAiberg, F Physiologic 24-Hour Penodicity, General and Procedural Considerations with Reference to the Adrenal Cycle Z Vitamm-Hormon u Fermentforsch 10225 (1959)

8 FrnNey, D J Statistical Methods in Biological Assays New York Haffner (1953)

9 Pittendrigh, C S In Circadian Rhythms and the Cillcadian Organization of Living Systems Cold Spring Harbor Symposia on Quant Biol, vol 25, Long Island Biol Assoc, New York, 1960, p 159

10 Halberg, $F$, Bitrner, J J, Gully, R J, Albrecht, $\mathrm{P} G$, \& Brackney, E I 24-Hour Penodicity and Audiogenic Convulsions in I Mice of Vanous Ages Proc Soc Exper Biol Med 88169 (1955)

11 Halberg, F, Bittner, J T, \& Gully, R T Twenty-four-hour Penodic Susceptibility to Audiogenic Convulsions in Several Stocks of Mice Fed. Proc 1467 (1955)

12 Matberg, F, Johinson, E A, Brown, B W, \& Bittner, J J Susceptibility Rhythm to E coll Endotoxın and Bioassay Proc Soc Exper Biol Med 103142 (1960)

13 Halberg, F \& Stevens, A N Susceptibility to Ouabain and Physiologic Circadian Penodicity Proc Minn Acad Sci 27 139 (1959)

14 Haus, E \& Halberg, F 24-Hour Rhythm in Susceptibility of C Mice to a Toxic Dose of Ethanol J Appl Physiol 14878 (1959)

15 Marte, E \& Halberg, F Circadian Susceptibility Rhylhm to Librum Fed Proc 20 305 (1961)

16 - In 'Circadian Systems,' Report of the Thirty-Ninth Ross Conf of Ped Res, edited by S J Fomon, p 52 Columbus Ross Laboratores (1961)

17 AGREN, G, WilANDER, O , \& JORPES, E Cyclic Changes in the Glycogen Content of the Liver and the Muscles of Rats and Mice Therr Bearing upon the Sensitivity of the 
Anumals to Insulin and Their Influence on the Unnary Output of Nitrogen Biochem J 25777 (1931)

18 Motrram, J C A Diumal Vanation in the Production of Tumors J Pathol. Bact 57 265 (1945)

19 EdLuND, Y \& Holmgren, H Experimentelle Studien des Verhaltens der Narkose zu verschiedenen Zeiten der 24 Stunden-Penode $\mathrm{Z}$ gesamt exper Medizin 10726 (1939)

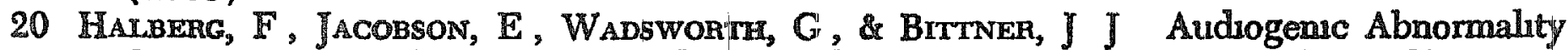
Spectra, Twenty-four Hour Periodicity, and Lightung Science 128657 (1958)

21 SavaGe, L R , RaO, M M, \& Halberg, F Test of Peak Values in Physiopathologic Time Senes Exper Med \& Surg 20309 (1962)

22 Halberg, F Some Physiological and Clinical Aspects of 24-Hour Penodicity The Journal-Lancet 7320 (1953)

23 Harberg, F \& Howard, $\mathbb{R}$ B 24-Hour Penodicity and Experimental Medicune Examples and Interpretations Postgrad Med 24349 (1958)

24 Davis, W M Day-Night Penodicity in Pentobarbital Response of Mice and the Influence of Socio-psychological Conditions Expenenta 18 235 (1962)

25 Davis, W M \& WEBB, O L A Circadian Rhythm of Chemoconvulsive Response Thresholds in Mice Med Exp 9263 (1963)

26 EMLEN, S T \& KEM, W Activity lihythm in Peromyscus Its Influence on Rates of Recovery from Nembutal Science 1421682 (1963)

27 Halberg, $\mathbb{F}$, Lowenson, $\mathbb{R}$, Winter, $\mathbb{R}$, Beamian, J, \& Adrans, $\mathbb{G}$ H Curcadian Systems Differences in Penod of Circadian Rhythms or in Their Component Frequencies Mmn Acad Sci 2853 (1960) 